\title{
New species of the Eiphosoma dentator (Fabricius, 1804) species-group (Hymenoptera, Ichneumonidae, Cremastinae) from Brazil
}

\author{
Melo, IF.*, Onody, HC. and Penteado-Dias, AM. \\ Departamento de Ecologia e Biologia Evolutiva, Universidade Federal de São Carlos - UFSCar, \\ Rod. Washington Luís, Km 235, SP-310, CP 676, CEP 13565-905, São Carlos, SP, Brazil \\ *e-mail: ivyfrizo@yahoo.com.br \\ Received April 14, 2011 - Accepted June 07, 2011 - Distributed May 31, 2012 \\ (With 9 figures)
}

\begin{abstract}
A new species of Eiphosoma Cresson, 1865 (Hymenoptera, Ichneumonidae) is described based on five specimens collected in organic crops areas in Araraquara and Cravinhos municipalities, São Paulo State, Brazil. A diagnostic key to the neotropical Eiphosoma dentator species-group is also provided.
\end{abstract}

Keywords: neotropical region, taxonomy, parasitoid.

\section{Nova espécie do grupo Eiphosoma dentator (Fabricius, 1804) (Hymenoptera, Ichneumonidae, Cremastinae) para o Brasil}

\begin{abstract}
Resumo
Descrição de uma nova espécie de Eiphosoma Cresson, 1865 (Hymenoptera, Ichneumonidae), baseada em cinco exemplares coletados em áreas de hortas orgânicas nos municípios de Araraquara e Cravinhos, no Estado de São Paulo, Brasil. Uma chave diagnóstica para as espécies neotropicais do grupo Eiphosoma dentator é também apresentada neste trabalho.
\end{abstract}

Palavras-chave: região neotropical, taxonomia, parasitoide.

\section{Introduction}

Eiphosoma Cresson (1865) is a New World genus of Cremastinae (Ichneumonidae) comprising about 52 described neotropical species, 17 of which occur in Brazil (Costa Lima, 1953; Gauld, 2000; Yu et al., 2005; Fernández-Triana and Ravelo, 2007). The majority of Eiphosoma species occur in lowland habitats, and they are rarely encountered above $1500 \mathrm{~m}$. The genus includes some of the commonest ichneumonid species to be seen and collected in open degraded habitats (Gauld, 2000).

Several species occur in agroecosystems and are important natural enemies of lepidopterous pests (Ashley et al., 1982; Gauld, 2000; Pozo, 2000; FernándezTriana and Ravelo, 2007; Onody et al., 2009). Eiphosoma species are recorded as attacking a range of pyralid species like Diaphania hyalinata Linnaeus (Lepidoptera, Pyralidae) (Gauld, 2000), although the species most commonly found E. laphygmae, attacks noctuids (Townes and Townes, 1966). There are multiple hosts reported in previous papers, but all require confirmation because the identification of species of Eiphosoma it is often suspected due to the fact that many species have many similarities between them (Gauld, 2000).
Whilst the genus Eiphosoma is very distinguishable and well-known, the species are difficult to identify (Gauld, 2000) due to the small number of taxonomic works and the recurrent use of coloration patterns. There have been three taxonomic reviews in the last century that treated New World tropics Eiphosoma species: Cockerell (1913), Costa Lima (1953) and Gauld (2000) (Fernández-Triana and Ravelo, 2007).

Eiphosoma gauldi sp. nov. is a new neotropical Eiphosoma species that belongs to the E. dentator speciesgroup. This group is characterised by the metapleuron densely punctate all over, straight ovipositor and uniformly hyaline fore wing. Only four neotropical species belonging to this group have been registered until now: E. dentator (Fabricius, 1804); E. mexicanum Cresson, 1874; E. yoron Gauld, 2000 and E. bioeco Fernández-Triana and Ravelo, 2007.

This paper describes Eiphosoma gauldi sp. nov., captured during a study carried out in agro-ecosystems in São Paulo state. A key to Neotropical Eiphosoma dentator species-group is also presented. 


\section{Material and Methods}

This study is based on the examination of five Eiphosoma specimens that have been collected in agroecosystems, in Araraquara $\left(21^{\circ} 44,5^{\prime} \mathrm{S}\right.$ and $48^{\circ} 13,04^{\prime} \mathrm{W}$ ) and Cravinhos ( $21^{\circ} 18^{\prime} 54^{\prime \prime} \mathrm{S}$ and $47^{\circ} 47^{\prime} 39^{\prime}$ ' W) municipalities, in São Paulo state, using Malaise and Moericke traps. The specimens collected were deposited in the collection of the Departmento de Ecologia e Biologia Evolutiva da Universidade Federal de São Carlos, São Carlos, SP, Brazil (DCBU). The terminology follows Gauld (2000) and Fernández-Triana and Ravelo (2007).

\section{Results}

\section{Key to Neotropical Eiphosoma dentator species-group}

1. Pleural carina absent posteriorly, only indicated by an impressed groove (Figure 8). Fore wing sparsely hirsute; distal abscissa of $M$ and $C u 1$ spectral or absent (Figure 9); areolet absent or small and petiolate above, petiole usually longer than height of areolet...........

E. dentator (Fabricius)

- Pleural carina complete (Figure 6). Fore wing not sparsely hirsute; distal abscissa of $M$ and $C u l$ more or less complete to margin; areolet always present if petiolate above, petiole shorter than height of areolet. ....2

2. Upper mandibular teeth distinctly or slightly longer than lower ones. Propodeum with a short black stripe, at most only reaching the centre..... ....3

- Mandibular teeth more or less equal (Figure 4), sometimes lower slightly longer. Black strip on the propodeum not short, reaching at least the posterior

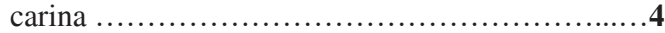

3. Malar space 0.2-0.3 times as long as basal mandibular width. Fore wing with shorter petiole compared to dorsal end of areolet. Upper end of epomia very weakly raised, forming a low rounded swelling laterally... .E. yoron Gauld

- Malar space 0.3-0.4 times as long as basal mandibular width. Fore wing with longer petiole compared to dorsal end of areolet. Epomia raised, without low and rounded swollen flange............

E. bioeco Fernández-Triana and Ravelo

4. Malar space about 0.3 times as long as basal mandibular width. Scutellum with one or two punctures. Hind wing with five distal hamuli.

E. mexicanum Cresson

- Malar space about 0.6 times as long as basal mandibular width. Scutellum densely punctate centrally (Figure 5). Hind wing with four distal hamuli......................................... gauldi sp. nov.

Eiphosoma gauldi sp. nov. Melo, Onody and PenteadoDias

\section{Material examined:}

- Holotype: 19 Palmares farm - coffee cultivars, 24/ III/ 2006, Moericke trap, R.I.R. Lara and team col., Cravinhos, SP, Brazil.
- Paratypes: $2 \hat{\jmath}$ organic cultivars, 10/IV/2006, Malaise trap, H. C. Onody col., Araraquara, SP, Brazil; 2 o organic cultivars, 23/ VI to 07/ VII/2006, Malaise trap, H. C. Onody col., Araraquara, SP, Brazil.

- Etymology: The specific name "gauldi" is in memoriam and honor of Ian D. Gauld for his contributions to the Ichneumonidae knowledge.

- Diagnosis: E. gauldi runs to couplet 17 in Gauld (2000) key to Eiphosoma species. It is, however, different from $E$. mexicanum and $E$. yoron. The new species most closely resembles $E$. mexicanum by having the mandible more or less equally bidentate (in the others species the lower mandibular tooth is shorter than the upper ones) and the lower part
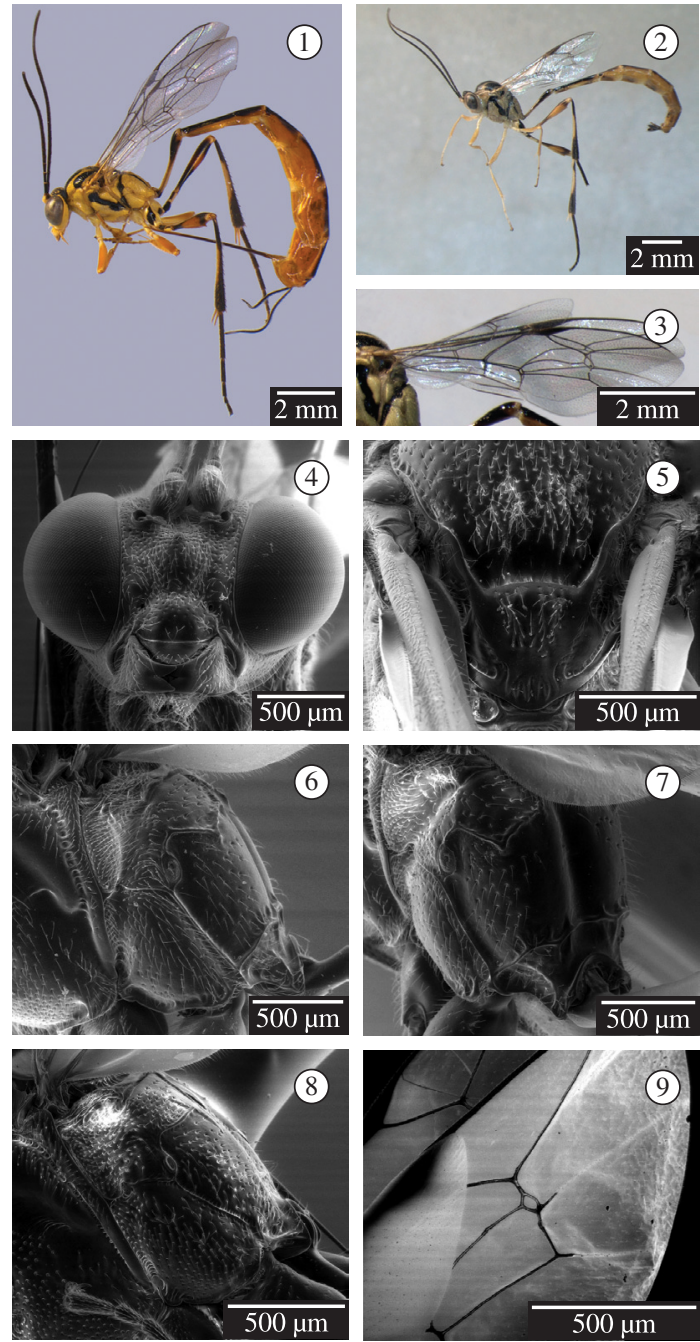

Figures 1-9. Eiphosoma gauldi sp. nov., holotype $\bigcirc$, habitus; Eiphosoma gauldi sp. nov., paratype $\widehat{\delta} 2$, habitus; 3 , fore wing; 4, frontal view of head; 5, mesoscutum and scutellum ; 6, metapleuron; 7 propodeum; 8-9: Eiphosoma dentator (Fabricius, 1804) 8, metapleuron; 9, fore wing. 
of the occipital carina not meeting the hypostomal carina. However E. gauldi sp. nov. has a scutellum densely punctate all over, hind wing with only four distal hamuli and a longer malar space.

\section{Description}

Female- Large sized species (Figure 1), fore wing length $6 \mathrm{~mm}$ (Figure 3). Mandible weakly tapered towards distal end, with teeth more or less equal (Figure 4); clypeus, in profile, convex, malar space about 0.6 times as long as basal mandibular width (Figure 4); posterior ocellus separated from eye by $1 \times$ its own diameter. Pronotum with dorsal end of epomia raised; mesoscutum strongly punctate (Figure 5); scutellum more or less flat with punctures (Figure 5), mesopleuron with regularly punctate except in the black diagonal stripe; epicnemial carina reaching anterior end of pleuron about half way up pronotum; sternaulus strongly impressed anteriorly; metapleuron regularly punctate over entire surface (Figure 6); submetapleural carina present and moderately elevated (Figure 6). Propodeum usually smooth in the central furrow, laterally sparsely punctate; anterior and posterior tranverse carina complete (Figure 7); area basalis smooth, laterally often confluent with area postero externae. Hind leg with trochantellus, in dorsal view, $0.7 \times$ as long as the trochanter; hind tibia and tarsus densely spinose; hind tarsal claw with long stout pectinae to the end. Fore wing with areolet large, obliquely quadrate, shortly petiolate above (Figure 3 ). Hind wing with 4 distal hamuli. Ovipositor straight 1.1-1.3× as long as hind tibia; ovipositor sheath with long and dense pubescence.

Head yellow with frons centrally, interocellar area, part of occiput and gena black; mesosoma yellow with three longitudinal black marks on the mesoscutum, distal end of scutellum, a diagonal stripe and the anterior margin of metapleuron, anterior margin and median long stripe on propodeum black. Metasoma yellowish brown with apical tergite I and tergite II black. Anterior two pairs of legs yellow; hind legs yellow with spots on inner and outer sides of coxa, trochanter, apical and basal bands of femur, broad basal and apical bands on tibia and entire tarsus black. Wings hyaline, pterostigma dark brown.

- Male (Figure 2): Similar to female, but propodeum is more punctate.

- Variation: The diagonal black stripe on mesopleuron sometimes is interrupted and the size of black marks near propodeal spiracles can be variable.

- Host: unknown.

Acknowledgements - The authors are grateful to FAPESP (Fundação de Amparo à Pesquisa do Estado de São Paulo) and to CAPES (Coordenação de Aperfeiçoamento de Pessoal de Nível Superior) for financial support. Thanks also to Marcelo Oyafuso for facilitating the fieldwork, Daniell Fernandes for collection of one specimen, and Luciana Bueno dos Reis Fernandes for the support with the pictures.

\section{References}

ASHLEY, TR., WADDILL, VH., MITCHELL, ER. and RYE, J., 1982. Impact of native parasitoids on the fall armyworm, Spodoptera frugiperda (Lepidoptera: Noctuidae) in south Florida and release of the exotic parasitoid Eiphosoma vitticole (Hymenoptera: Ichneumonidae). Environmental Entomology, vol. 11, p. 833-837.

COCKERELL, TDA., 1913. New parasitic Hymenoptera of the genus Eiphosoma. Proceedings of the United States National Museum, vol. 46: 61-64.

COSTA LIMA, A., 1953. Espécies de Eiphosoma Cresson (Hymenoptera, Ichneumonidae, Ophioninae). Arquivos do Museu Nacional Rio de Janeiro, vol. 42, p. 175-189.

CRESSON, ET., 1865. The Hymenoptera of Cuba. Entomological Society of Philadelphia, vol. 4, p. 1-200.

FERNÁNDEZ-TRIANA, JL. and RAVELO, HG., 2007. A taxonomic review of Cuban Eiphosoma Cresson (Hymenoptera: Ichneumonidae) with biogeographical notes. Zootaxa, vol. 1655, p. $49-61$.

GAULD, ID., 2000. The Ichneumonidae of Costa Rica, 3. Memoirs of the American Entomological Institute, vol. 63, p. 50-120.

ONODY, HC.; MELO, IF.; PENTEADO-DIAS, AM. and DIAS-FILHO, MM., 2009. New species of Eiphosoma Cresson 1865 (Hymenoptera, Ichneumonidae, Cremastinae) from Brazil. Brazilian Journal of Biology, vol. 69, n. 4, p. 1205-1206. http:// dx.doi.org/10.1590/S1519-69842009000500028

POZO, E., 2000. Diaphania hyalinata (L.) (Lepidoptera: Pyralidae) en la región central de Cuba. Bionomía y lucha biológica. Santa Clara: Universidad Central de Las Villas. 124 p. Tese de Doutorado.

TOWNES, H., and TOWNES, M., 1966. A catalogue and reclassification of Neotropic Ichneumonidae. Memoirs of the American Entomological Institute, vol. 8, p. 1-367.

YU, DS., ACHTERBERG, C. and HORSTMANN, K., 2005. World Ichneumonoidea 2004: taxonomy, biology and distribution. Vancouver: Taxapad. CD-ROM. 
